\title{
To the analysis of the flora of water bodies and watercourses of the city of Tobolsk (Tyumen region) and cities of the Vyatka-Kama Cis-Urals
}

\author{
Olga Kapitonova ${ }^{1,2, *}$ \\ ${ }^{1}$ Tobolsk complex scientific station of Ural Branch of the Russian Academy of Sciences, 626152 \\ Tobolsk, Russia \\ ${ }^{2}$ Papanin Institute for Biology of Inland Waters of the Russian Academy of Sciences, 152742 Borok, \\ Russia
}

\begin{abstract}
The flora of water bodies and watercourses of the city of Tobolsk is composed of 266 species of macrophytes, including both higher plants and macroalgae. This indicator is higher than the number of macrophyte species in the previously studied cities of the Vyatka-Kama Cis-Urals, while the ratio of ecological groups remains the same. The taxonomic richness and ecological diversity of the hydrophilic component of urban floras depends on a number of factors: 1) the presence and diversity within the urban landscape of habitats inhabited by aquatic and semi-aquatic plants; 2) the position of the city's territory in the system of regional land subdivisions within the physical-geographical country; 3 ) the age of the city. The composition of macrophytes is not affected by the size of the urban area and the geographical position of the city within a region.
\end{abstract}

\section{Introduction}

Flora of water bodies (watercourses) is a set of species of aquatic plants and plants entering the water, found in a water body (watercourse) or in water bodies (watercourses) of a territory [1]. In hydrobotany, the object of research is macrophytes - large plants visible to the naked eye, regardless of their taxonomic position and ecological confinement (higher plants and large multicellular algae) [1]. Thus, the flora of water bodies and watercourses is composed of aquatic macrophytes.

Against the background of an increase in the level of urbanization throughout the world and in individual regions, it is an important task to understand the mechanisms of adaptation of flora to the conditions of the urban environment. It is shown that of all the ecological components of the flora of urban settlements, it is the hygrophilic component of urban floras that first of all reacts to the intensification of urbanization by reducing the share in the overall structure of the flora of cities [2]. In 1995-2015, we studied the flora of water bodies and watercourses in six cities of Udmurt Republic (Izhevsk, Glazov, Votkinsk, Sarapul, Mozhga, Kambarka) located within the Vyatka-Kama Cis-Urals (VKCU). We found that within the urban landscapes there is a decrease in the taxonomic diversity of the

* Corresponding author: kapoa.tkns@gmail.com 
regional flora of aquatic macrophytes. It occurs due to a decrease in the proportion of hydrophytes with a narrow ecological confinement, as well as species with a narrow range $[3,4]$. It is of interest to what extent this pattern manifests itself in other regions that are close in physical and geographical conditions.

Within the framework of the set task, we studied the flora of aquatic macrophytes of the city of Tobolsk (Tyumen region), located within Western Siberia. The purpose of this study is to perform a comparative analysis of the identified flora of water bodies and watercourses of Tobolsk with the flora of aquatic macrophytes of the previously studied cities of the VKCU.

\section{Natural conditions}

VKCU is located in the east of the European part of Russia, at the transition point of the Russian Plain to the foothills of the Urals. Within this territory, we conducted research during 1995-2015 in six cities (Fig. 1) that differ in their structural and organizational characteristics: in a large city, the capital of the Udmurt Republic, Izhevsk (N56 $51^{\prime}$

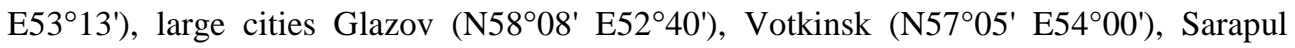

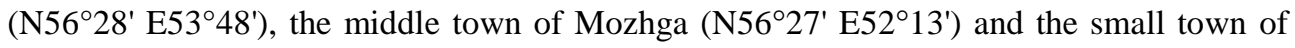

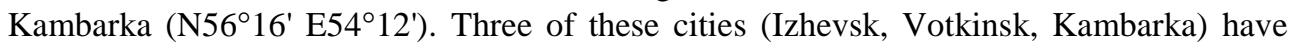
large water bodies - reservoirs built in 1759-1767 on small rivers. The cities of Glazov and Sarapul are located on the banks of large rivers - respectively, Cheptsa and Kama, the city of Mozhga is located on the banks of a small river.

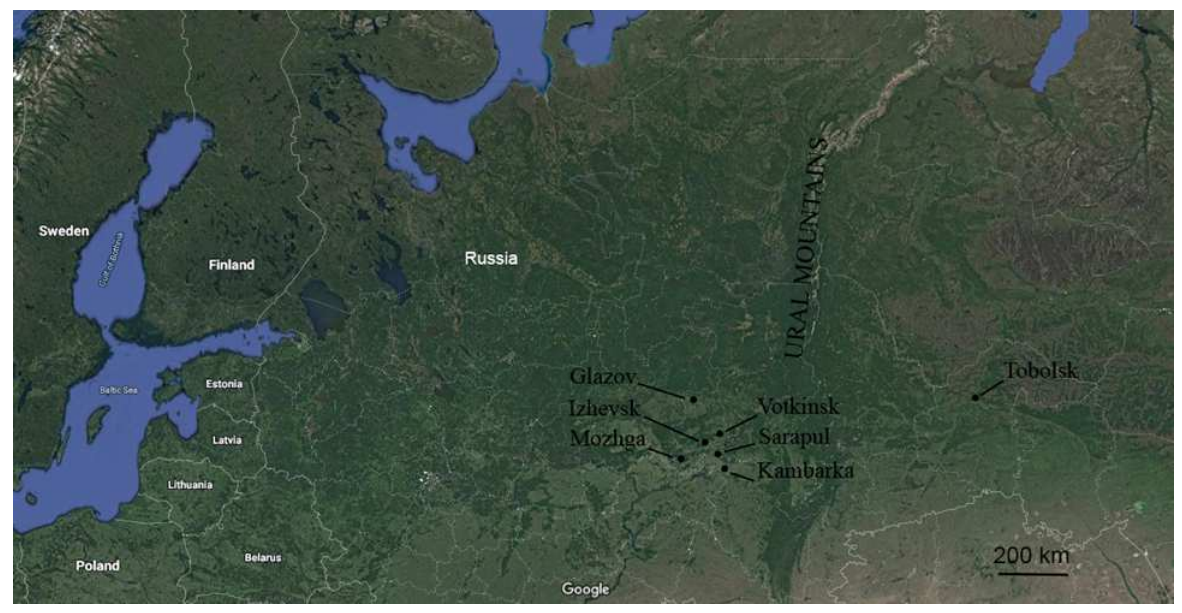

Fig. 1. The position of the cities of the Vyatka-Kama Cis-Urals and Tobolsk on the territory of Russia

Tobolsk (N58 $11^{\prime} 43^{\prime \prime}$ E68 $\left.15^{\prime} 29^{\prime \prime}\right)$ is a city in the Tyumen region, founded in 1587. It is located within the West Siberian Plain, at the confluence of two large rivers - Tobol and Irtysh (Fig. 1). The main part of the city is located on the right bank of the Irtysh River, two microdistricts (Levoberezhje and Sumkino) are located on the left bank of the river. The total area of the city is $222 \mathrm{~km}^{2}$. The position of Tobolsk at the southern limit of the taiga natural zone determines the general southern taiga character of the vegetation cover. The high level of water content in the territory is due to the position of a part of the urban area in the floodplain of Irtysh River and the presence of numerous and diverse water bodies, both natural (large rivers Tobol and Irtysh and their tributaries, oxbows, channels, flooded areas of low-lying (minerotrophic) bogs, swampy forests and floodplain meadows), and anthropogenic (flooded quarries, excavations, drainage ditches and canals, ponds, roadside 
ditches, puddles). According to geobotanical zoning, the territory of the city is included in the Tobolsk-Irtysh district of dark coniferous birch and dark coniferous pine grass forests in combination with lowland and raised bogs [5]. In terms of its physical and geographical characteristics, Tobolsk is close to the city of Glazov and also belongs to the category of large cities with a population of about 100 thousand people.

\section{Methods}

We have been conducting research in Tobolsk since 2015. The main materials for the work were hydrobotanical collections and descriptions of aquatic and semi-aquatic vegetation, performed by the author.

In accordance with the definition of the concept of "flora of macrophytes" [1], we took into account all plants naturally occurring in aquatic and semi-aquatic ecotopes during the summer low-water period. In total, the research covered an area of about $500 \mathrm{~km}^{2}$, including both the territory of the city and its environs. When forming the list of the studied flora, the orders and families of flowering plants were arranged in accordance with the APG-IV angiosperm system [6]; their volume is given according to the same system. The nomenclature of vascular plants is given mainly according to the "Conspectus of the flora of Asian Russia" [7] with clarification from the database "World Checklist of Selected Plant Families (WCSP)" [8]. The orders and families, as well as the nomenclature of taxa of bryophytes, are arranged according to the lists of mosses [9] and liverworts [10].

During the systematic processing of the material, the species of macrophytes were divided into two typological groups, according to the recommendations of $\mathrm{A} . \mathrm{V}$. Shcherbakov: "aquatic core" of the flora and semi-aquatic component [11]. The classification scheme of the ecological structure of the flora was adopted according to V.G. Papchenkov [12] with minor changes.

\section{Results}

\subsection{Systematic structure}

We found that the flora of macrophytes of Tobolsk includes 266 plant species (Table 1). The richest families are shown in Fig. 2. Of the genera, the richest in species are Carex (15 species), Potamogeton (13), Salix (12), Juncus (8), Ranunculus (7), Persicaria, Rumex, Typha, and Sphagnum (5 species each).

Table 1. Systematic composition of the macrophyte flora of the city of Tobolsk

\begin{tabular}{|l|l|c|c|c|c|}
\hline \multicolumn{1}{|c|}{ Divisions } & \multicolumn{1}{c|}{ Classes } & $\begin{array}{c}\text { Number } \\
\text { of orders }\end{array}$ & $\begin{array}{c}\text { Number } \\
\text { of families }\end{array}$ & $\begin{array}{c}\text { Number } \\
\text { of genera }\end{array}$ & $\begin{array}{c}\text { Number } \\
\text { of species }\end{array}$ \\
\hline Chlorophyta & Ulvophyceae & 1 & 1 & 1 & 1 \\
\hline Charophyta & Charophyceae & 1 & 1 & 2 & 4 \\
\hline Marchantiophyta & Marchantiopsida & 2 & 4 & 5 & 5 \\
\hline \multirow{2}{*}{ Bryophyta } & Sphagnopsida & 1 & 1 & 1 & 5 \\
\cline { 2 - 6 } & Bryopsida & 2 & 9 & 14 & 24 \\
\hline Lycopodiophyta & Lycopodiidae & 1 & 1 & 1 & 1 \\
\hline \multirow{2}{*}{ Polypodiophyta } & Equisetidae & 1 & 1 & 1 & 3 \\
\cline { 2 - 7 } & Polypodiidae & 1 & 1 & 1 & 1 \\
\hline Spermatophyta & Magnoliopsida & 25 & 48 & 104 & 222 \\
\hline \multicolumn{1}{|c|}{ Total: $\mathbf{7}$} & $\mathbf{9}$ & $\mathbf{3 5}$ & $\mathbf{6 7}$ & $\mathbf{1 3 0}$ & $\mathbf{2 6 6}$ \\
\hline
\end{tabular}




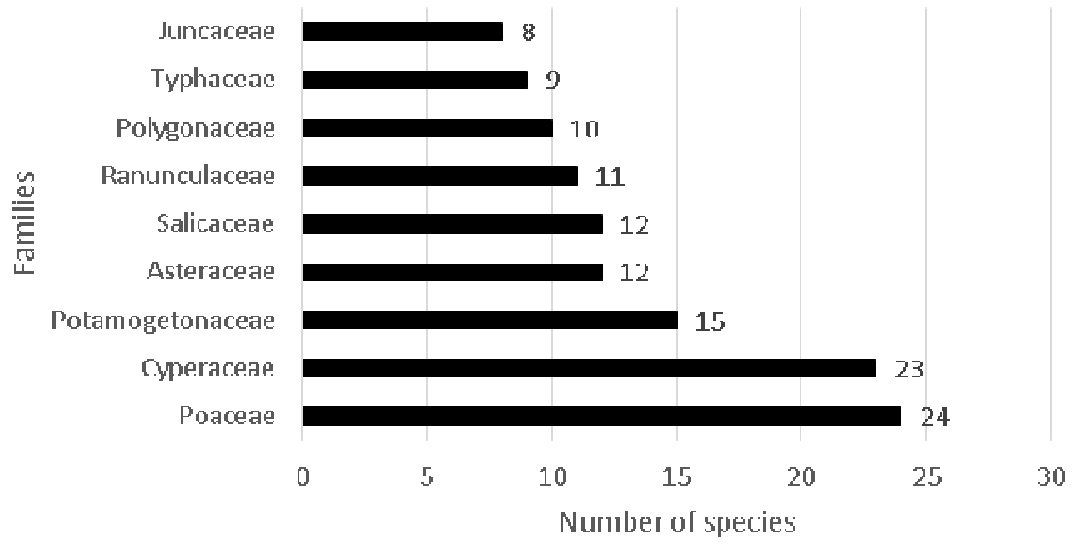

Fig. 2. The head part of the family-species spectrum of the macrophyte flora of the city of Tobolsk

The studied flora turned out to be richer in comparison with the flora of macrophytes in the cities of VKCU, and the number of species included in the "aquatic core" of the flora is comparable to the number of hydrophytes known for such a large city as Izhevsk (Table 2). Such a high taxonomic richness of the hydrophilic flora of Tobolsk indicates the presence of a wide range of habitats, both natural and anthropogenic, inherent in aquatic plants.

The flora of macrophytes of Tobolsk shows an average and moderate level of similarity with the flora of macrophytes in the cities of VKCU when comparing both complete floras and their hydrophilic components (Table 2, fig. 3). This gives grounds to say that there are some factors that influence the floristic composition of macrophytes in Tobolsk.

Table 2. The values of the Jacquard coefficient $\left(\mathrm{K}_{\mathrm{j}}\right)$ of the macrophyte flora of the cities of the VKCU and Tobolsk

\begin{tabular}{|c|c|c|c|c|c|c|c|}
\hline Cities & 1 & 2 & 3 & 4 & 5 & 6 & 7 \\
\hline 1 & $266(47)$ & $0.50(\mathbf{0 . 5 4})$ & $\mathbf{0 . 5 2}(\mathbf{0 . 4 9})$ & $0.31(0.28)$ & $\mathbf{0 . 5 2}(\mathbf{0 . 5 1})$ & $0.28(0.29)$ & $\mathbf{0 . 5 7}(\mathbf{0 . 5 0})$ \\
\hline 2 & 0.53 & $257(49)$ & $0.64(0.64)$ & $0.39(0.36)$ & $0.65(\mathbf{0 . 7 0})$ & $0.35(0.40)$ & $\mathbf{0 . 6 5}(0.59)$ \\
\hline 3 & 0.48 & 0.66 & $197(38)$ & $\mathbf{0 . 6 0}(0.50)$ & $\mathbf{0 . 7 0 ( 0 . 7 2 )}$ & $0.45(0.42)$ & $\mathbf{0 . 7 0}(\mathbf{0 . 6 7})$ \\
\hline 4 & 0.35 & 0.48 & 0.55 & $153(29)$ & $0.42(0.41)$ & $0.44(0.42)$ & $0.47(0.52)$ \\
\hline 5 & 0.46 & 0.66 & 0.66 & 0.47 & $194(35)$ & $0.44(0.43)$ & $\mathbf{0 . 7 0}(0.63)$ \\
\hline 6 & 0.32 & 0.46 & 0.48 & 0.51 & 0.48 & $122(17)$ & $0.39(0.42)$ \\
\hline 7 & 0.49 & 0.62 & 0.61 & 0.55 & 0.64 & 0.47 & $198(40)$ \\
\hline
\end{tabular}

Note. The lower left part of the table shows $\mathrm{K}_{\mathrm{j}}$ values for the total macrophyte flora of the cities, the upper right part of the table shows only for hydrophytes (in brackets are the values for aquatic flora in a broad sense - hydrophytes, helophytes and hygrohelophytes); the coefficient values having higher values for the aquatic component in comparison with the full macrophyte flora of the studied cities are highlighted in bold. The diagonal indicates the number of species in the flora, in brackets - the number of species in the "aquatic core" of the flora. 1 - Tobolsk, 2 - Izhevsk, 3 - Glazov, 4 Sarapul, 5 - Votkinsk, 6 - Mozhga, 7 - Kambarka,

First of all, this is the position of the city on the territory of Western Siberia, which determines the absence of some European species in the flora, as well as the presence of a number of Asian species that are absent in the VKCU. In addition, the location of Tobolsk on the banks of two large rivers with a submeridional flow direction enriches the flora with southern geographical elements. Also, the general high level of waterlogging in the territory of Western Siberia and Tobolsk in particular, which creates favorable conditions for the growth of many wetland species within the city. The latter reflects the closeness of the 
hydrophilic component of the Tobolsk flora with the aquatic flora of the city of Kambarka, within which there are also swamps with watered deepening. Obviously, the age of the city should be considered as an independent factor, which is associated with the degree of transformation of the territory and the presence of anthropogenic flooded ecotopes.
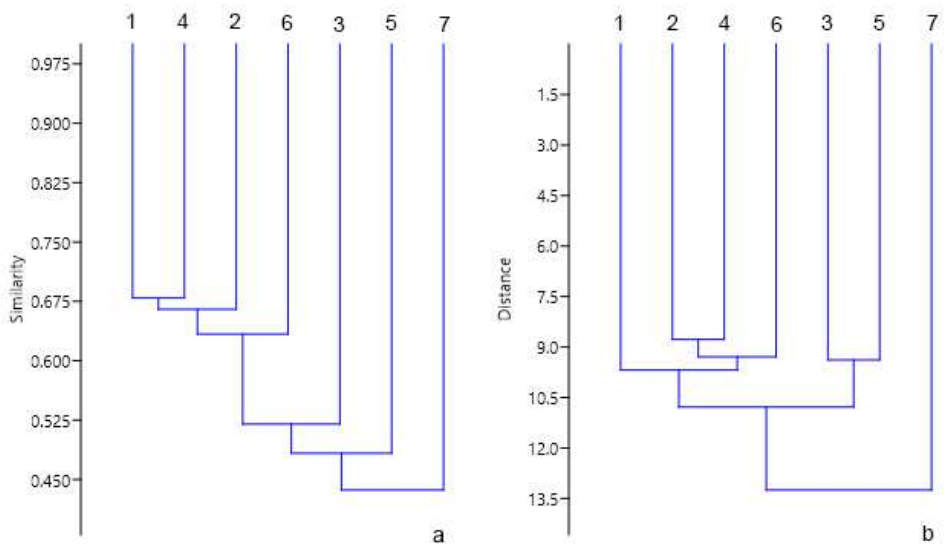

Fig. 3. Dendrogram of the similarity of the species composition of the macrophyte flora of the city of Tobolsk and the cities of the VKCU; $a$ - Jacquard coefficient, b - Paired group (UPGMA). Euclidian distance. 1 - Izhevsk, 2 - Glazov, 3 - Sarapul, 4 - Votkinsk, 5 - Mozhga, 6 - Kambarka, 7 - Tobolsk

\subsection{Ecological structure}

In the ecological structure of the studied flora, a group of classes of coastal (near-water) plants dominates (Fig. 4). The smallest number of species is contained in the group of classes of real aquatic plants that make up the "aquatic core" of the flora. The revealed ratio of ecological groups in the flora of macrophytes of Tobolsk is also typical for the studied cities of the VKCU, where the share of the "aquatic core" ranges from 13.93\% (Mozhga) to $20.2 \%$ (Izhevsk), on average $-19.87 \%$.

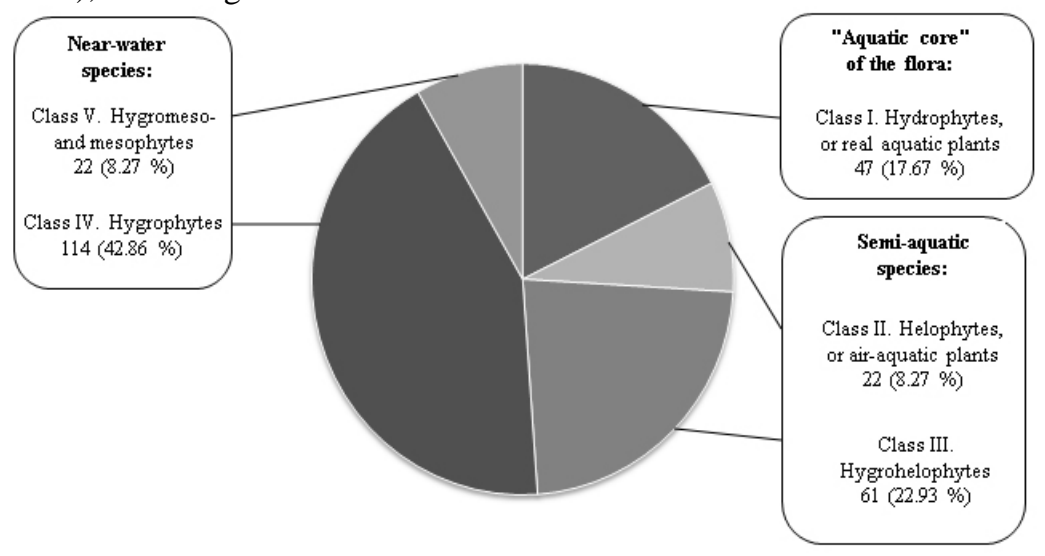

Fig. 4. Ecological structure of the macrophyte flora of the city of Tobolsk

\section{Conclusion}

We found that the flora of water bodies and watercourses of the city of Tobolsk is composed of 266 species of macrophytes, including both vascular plants and bryophytes 
and macroalgae. This indicator is higher than the number of macrophyte species in the cities of the VKCU studied by us earlier, while the ratio of ecological groups is the same as in the cities of the VKCU. The data obtained indicate that the taxonomic richness and ecological diversity of the hydrophilic component of urban floras depends on a number of factors. These include: 1) the presence and diversity within the urban landscape of habitats inhabited by aquatic and semi-aquatic plants; 2) the position of the city's territory in the system of regional (zonal-meridional) land subdivisions within the physical-geographical country; 3) the age of the city. The composition of macrophytes is not affected by the size of the urban area and the geographical position of the city within a limited region.

The author thanks R.E. Romanov for the identification of macroalgae and A.G. Bezgodov for help in identifying bryophytes.

\section{References}

1. V. G. Papchenkov, A. V. Shcherbakov, A. G. Lapirov. Basic hydrobotanical concepts and related terms. Hydrobotany: Methodology, Methods: Materials of the School of Hydrobotany, 8-12 April 2003, Borok, Russia. Rybinsk (2003)

2. N. G. Ilminskikh, Florogenesis in an urbanized environment (Yekaterinburg, Ural Branch of the Russian Academy of Sciences, 2014)

3. O. A. Kapitonova, Botanical and geographical research. Kamelinian readings (Perm, 2019)

4. O. A. Kapitonova, Transactions of Papanin Institute for Biology of Inland Waters RAS. 93(96) (2021)

5. A. G. Voronov, G. A. Mikhailova. Atlas of the Tyumen Region (Moscow-Tyumen, 1971)

6. M. W. Chase, M. J. M. Christenhusz, M. F. Fay, J. W. Byng, W. S. Judd, D. E. Soltis, D. J. Mabberley, A. N. Sennikov, P. S. Soltis, P. F. Stevens. Bot. J. of the Linnean Soc. 181(1) (2016)

7. K. S. Baikov (ed.). Conspectus of the flora of Asian Russia: vascular plants. (Novosibirsk, 2012)

8. World Checklist of Selected Plant Families (WCSP). Facilitated by the Royal Botanic Gardens, Kew. URL: http://wcsp.science.kew.org/ (date of access: 08.05.2021)

9. M. S. Ignatov, O. M. Afonina, E. A. Ignatova, with contribution on regional floras from: A. Abolina, T. V. Akatova, E. Z. Baisheva, L. V. Bardunov, E. A. Baryakina, O. A. Belkina, A. G. Bezgodov, M. A. Boychuk, V. Ya. Cherdantseva, I. V.

Czernyadjeva, G. Ya. Doroshina, A. P. Dyachenko, V. E. Fedosov, I. L. Goldberg, E. I. Ivanova, I. Jukoniene, L. Kannukene, S. G. Kazanovsky, Z. Kh. Kharzinov, L. E. Kurbatova, A. I. Maksimov, U. K. Mamatkulov, V. A. Manakyan, O. M. Maslovsky, M. G. Napreenko, T. N. Otnyukova, L. Ya. Partyka, O. Yu. Pisarenko, N. N. Popova, G. F. Rykovsky, D. Ya. Tubanova, G. V. Zheleznova, V. I. Zolotin. Check-list of mosses of East Europe and North Asia. Arctoa. 15 (2006)

10. N. A. Konstantinova, V. A. Bakalin, E. N. Andrejeva, A. G. Bezgodov, E. A. Borovichev, M. V. Dulin, Yu. S. Mamontov. Checklist of liverworts (Marchantiophyta) of Russia. Arctoa. 18 (2009)

11. A. V. Shcherbakov. Bulletin MOIP. Dept. Biol. 99 (2) (1994)

12. V. G. Papchenkov. Vegetation cover of water bodies and watercourses of the Middle Volga region (Yaroslavl, 2001) 